\title{
APPLICATION OF 'SIX RIGHTS” ON MEDICATION ADMINISTRATION BY NURSE AND PATIENT SATISFACTION
}

\author{
Imelda Rahmayunia Kartika, Vivi Melani \\ Nursing Program, STIKes Fort De Kock Bukittinggi \\ imelda.rahmayunia@fdk.ac.id
}

\begin{abstract}
Introduction: Giving the medications, nurse should pay attention to the principles of "six of rights", namely: right of patient, right medication, right dose, right way, right time, and right documentation. There are more than a half of nurses in a ward who are not provide medications in accordance with the Standard Operational Procedure (SOP). The purpose of this study was to determine of the relationship between applications of Standard Operational Procedure (SOP) six rights of medication administration by nurses and patient satisfaction. Methods: This study was using cross sectional design. There were 30 respondents taken by accidental sampling. This research was conducted in February 2017. Data collection used questionnaires and observation. Chi-Square test was used to analyze data. It can be known from 30 respondents who had six right in application of medication administration was performed good (50\%) then respondents were satisfied $(50 \%)$. Results: The results showed the significant relationship between the six rights of medication administration by nurse and the level of patient satisfaction $(p=0.003)$. Conclusion: It can be inferred that the higher interaction that occurs between nurse and patient in applying the principles of medication administration, it will higher patient satisfaction. Nurses suggested applying the six rights during medication administration.
\end{abstract}

Keywords: patient satisfaction, six rights on medication administration

\section{INTRODUCTION}

Quality healthcare can satisfy every health care service in accordance with the level of satisfaction (Rusdiana, 2015). Nowadays, healthcare quality focuses on the outcome of the whole services delivered by the hospital. Patient satisfaction is the one of the indicator of healthcare quality services (Brooks-Carthon, et al, 2011). Patient satisfaction with nursing care in a hospital is a measure of the patient's perception of the medical care (patients received) and healthcare system provided by nurses (Kartika, 2015). Patient satisfaction is a very important factor for evaluating the quality of nursing services performed by nurses in hospitals (Aiken et al., 2012). Caring behavior of nurses is one of the aspects related to nursing services and affect the quality of care and patient satisfaction (Abdul, Saleh \& Sjattar, 2013). Satisfaction is a comparison of the quality of services obtained with the wishes, needs and expectations. The level of satisfaction is a function of the difference between the perceived performances with expectations. If the performance below expectations, then the customer will feel disappointed. Then, while the performance is as expected, then the customer will be satisfied. Patients satisfactoryon nursing care services are also recommended, so that will impact on improving income of the hospital (Nursalam, 2014).

Patients also a customer of the services rendered by a medical institution (hospital). In the hospital, there are some health servicer, one of them are nurses. They are very important person as a key of patient satisfaction (Kutney-Lee et al., 2009). Satisfaction can be seen on the implementation of Standard Operating Procedures (SOP) provides by nurse. It very helpful to implement a nursing care quality (Kartika, 2014). One of the various roles done by nurse are medication administration. They must be able to think realistically about the importance of systematic evaluation of all aspects of nursing care that does not rule out the standard in the delivery medication. One of the nurses nursing care given to hospitalized patients is administration of medications (Hughes \& Blegen, 2008).

In the medication administration, nurses need to know about their patients who are difficult to swallow, patients who vomit, or the patient cannot take certain medications such as capsules, so that nurse must consider the Standard Operational Procedure $s$ (SOP) when giving a medication to a patient (Hilmawan, Suprapti, \& Solechan, 2014). Nurses should provide a variety of medications 
to patients safely. One way to maintain security in terms of providing the necessary medication is "six rights" principle. They are the right of patient, right ofmedication, right of doses, right of time, right of route, and right of documentation (Kaasalainen, 2014).

Based on a study conducted by researchers from Auburn University at 36 hospitals and Nursing Home in Colorado and Georgia, USA, in 2002, there were 3216 types of medication $(43 \%)$ given at the wrong time, $4 \%$ given the wrong medications, 312 species medicine, there is a $17 \%$ given the wrong dose (Kuntarti, 2013). Another study of (McLeod, Barber, \& Franklin, 2015) on the application of the principle of the six rights in the administration of medications by nurses pointed out that nurses are not applying the principle of the six rights application in medication delivery as a whole. There were $81.4 \%$ of nurses are already doing the right dose, $70 \%$ of nurses are already doing on time, $5.7 \%$ of nurses do not invoke the name of the patient when giving medications, $98.9 \%$ of nurses have not been applying the principle of the right way, $10 \%$ of nurses is not appropriate documentation and to note that $100 \%$ of nurses is not appropriate medication.

The implementation of the "six rights" is required by the nurse as legal liabilities to the actions taken are in accordance with the established procedure. Given the nurses who provide medications directly to patients and give it to some patients, but if it is in accordance with the standards specified procedure would then be able to minimize side effects and errors in delivering medication (Pirinen et al., 2015). Based on a preliminary study conducted by researchers in November 2016 in Military Hospital Bukittinggi through inpatient at Medical Department, there were 1600 patients with a population of 130 patients per month being treated regarding the administration of medications to the six principles of right.

Based on observations to the ten nurses who are giving the medication to patients, six nurses provide medications not in accordance with the Standard Operational Procedure (SOP) in the hospital. And based on the interview to the five patients showed that 3 patients $(60 \%)$ stated that less satisfied with the service during the administration of medications by nurses. Based on the phenomenon, researchers interested to know about the relationship between application of Standard Operational Procedure (SOP) of the "Six Rights" by Nurse and Patient Satisfaction in Military Hospital Bukittinggi by the Year of 2017.

\section{METHODS}

\section{Research Design}

This study used a descriptive, cross-sectional research design to know about the relationship between application of six right during medication administration as an independent variable and patient satisfaction as a dependent variable.

\section{Sample and Settings}

There were 30 patients participated to stated their satisfaction on medication administration by nurse. Sample taken by accidental sampling with inculsion criteria was the patients who had been treated for more than 3 days hospitalized.

\section{Data collection and analysis}

Data were analyzed using descriptive statistic to know distribution of each variable, and ChiSquare for relationship analysis on two variable with $\alpha 0,05$.

\section{Instrumentations}

Instrumentation used in this study was questionnaire about patient satisfaction and how the nurse act the medication administration. The questionnaire for patient satisfaction consist of 12 points using likert scale. Ratings for each statement in the form was ranging from "1" (Completely Dissatisfied), "2" (Almost Not Satisfied), "3" (Quite Satisfied) and"4" (Very Satisfied). Then, questionnaire on how the nurse act the medication administration consist of 6 point that reflect each procedures of "six rights". Total item for this questionnaire was 12 points devided into: right of patient (2 items), right of medication ( 2 items), right of dose (2 items), right of way (2 items), right of time (2 items), and right of documentation (2 items).

\section{Ethical considerations}

This study has obtained an approvement in Fort De Kock Health Science Research Division as sign in a letter No. 1771/PSS/LPPM/STIKes-FDK/V/2017. In collecting data, all respondents accepted informed consent to keep the legal rights for confidentially and anonymity. Then, the respondents who fit the inclusion criteria were given an explanation on how to answer the 
questionnaire and were coded without identifying persons who completed it.

\section{RESULTS}

The results of this study indicate that patient characteristics, half of the respondents $(50 \%)$ satisfied with the nursing service administration of medications six correct principles. Based on Table 1 can be inferred that among 30 respondents, there was a half (50\%)of the respondents stated the nurse implement "six rights" application based on Standart Operating Procedures (SOP).

Table 1 Response to the using of Standard Operational Procedure (SOP) "Six Right" By Nurse on Medication Administration $(\mathbf{n}=\mathbf{3 0})$

\begin{tabular}{lll}
\hline "Six Rights" by nurse & F & \% \\
\hline Less Good & 15 & 50 \\
Good & 15 & 50 \\
Total & 30 & 100 \\
\hline
\end{tabular}

Table 2 Patient Satisfaction

\begin{tabular}{lll}
\hline Patient satisfaction & F & \% \\
\hline Dissatisfied & 15 & 50 \\
Satisfied & 15 & 50 \\
Total & 30 & 100 \\
\hline
\end{tabular}

Table 2 shows that a half of the respondents $(50 \%)$ are satisfied for the nurse during medication administration among of 30 respondents.

In table 3 we can see that the 15 respondents were less good application of SOP "six rights" by the nurses, which were 12 respondents $(80 \%)$ are less satisfied, while 15 respondents were either do the "six rights" was three respondents $(20 \%)$ are satisfied. The results are comparable with patient satisfaction $(50 \%)$. The results showed that the $\mathrm{p}$ value $=$ 0.003 , it can be inferred that there is a correlation between application the principles of "six rights" on medication administration by nurses and patient satisfaction. Rated OR = 16,000 which means nurse who less application of "six rights" during medication administration has a chance 16 times to make patients less satisfied than with a nurse who implement the "six rights".

\section{DISCUSSIONS}

Standard Operational Procedure (SOP) is a guideline that has been written and should be done to get the most out of actions performed the medication administration by nurse (Hilmawan et al., 2014). According Adisasmito (2014) Standard Operational Procedure is a standardized series of written instructions regarding the various processes of the organization's activities, how and when it should be done, where and by whom do. Standard Operational Procedure guideline or reference to perform job duties in accordance with the functions and hospital performance assessment tool based on indicators - technical indicator. SOP purpose is to create a commitment to what is done to achieve an outcome that can satisfy patients.

The application of Standard Operational Procedure (SOP) "six rights" of medication administration by nurseare expected in a good way (Gonzales, 2012). Patients strongly hope the hospital can provide nursing services especially on giving medication maximally (Hughes \& Blegen, 2008). In the provision of nursing services, "six rights" principles, namely: the right of patient, the right ofmedication, the right of dose, the right of route, the right of time and the right of documentation. There are around $(50 \%)$ of nurses are already implement it unexpectedly, although there are still a number of nurses had done "six rights" on medication administration very well.

From application "six rights" onmedication administration there are some nurses have not done it well. The right of route is not applied (53.3\%) because many nurses do medication administration in a manner unfavorable to the patient that makes the patient less comfortable about how nurses perform medication administration. Nurse rarely inform the patient about how the medication were given. There are several factors that affect nurses did not aplicate sixrighton medication administration very well (Huynh et al., 2016). One of them arenurse did not have the knowledge, less about the experience of the principle, less of skills and lack of motivation. Then, when nurses perform the less competency in medication administration, it will influence the patient perception to the nursing services given by nurses. 
Table 3 Chi-square results of application of "six rights" by nurse (independent variable) on patient satisfaction (dependent variable)

\begin{tabular}{|c|c|c|c|c|c|c|c|c|}
\hline \multirow{3}{*}{$\begin{array}{l}\text { Application of "Six } \\
\text { Right" By Nurse }\end{array}$} & \multicolumn{4}{|c|}{ PatientSatisfaction } & \multicolumn{2}{|c|}{ Total } & \multirow{2}{*}{ p-value } & \multirow{2}{*}{ OR (CI 95\%) } \\
\hline & \multicolumn{2}{|c|}{ Dissatisfied } & \multicolumn{2}{|c|}{ Satisfied } & & & & \\
\hline & $\mathrm{f}$ & $\%$ & $\mathrm{~F}$ & $\%$ & $\mathrm{~F}$ & $\mathrm{n} \%$ & \multirow{4}{*}{0,003} & \multirow{4}{*}{16,000} \\
\hline Less Good & 12 & 80 & 3 & 20 & 15 & 100 & & \\
\hline Good & 3 & 20 & 12 & 80 & 15 & 100 & & \\
\hline Total & 15 & 50 & 15 & 50 & 30 & 100 & & \\
\hline
\end{tabular}

Satisfaction is a person's response to the fulfillment of the needs and expectations. The response is an assessment of a person to services fulfilling the needs and expectations of both the less and compliance fulfillment that exceed the needs and expectations (Otani et al., 2009). Satisfaction is a feeling of pleasure that one feels after comparing the results of a product with expectations. According to the findings, patient feel satisfied because the service is suitable to their expectations, during a visit to the hospital they already know more or less about the Military Hospital itself.

Expressions half of the respondents stated that the level of satisfied illustrates that the patient showed the nursing service is given quite well. The more positive assessment of respondents to the nursing care given to the patient (application of six rights on medication administration) the higher the satisfaction felt by the patient. Almost of patients stated that information about their medication was the important thing on the whole nursing care given by nurse (Kartika, 2016).

The satisfaction of the patient actually deciding factor was the expectation of the service, the adequacy perceived by the patient when treatment and the provision of adequate information, as well as technical competence possessed by the nurse (Senarath et al., 2013). While patients are not satisfied because there are some nurses who are not committed to the principles of six rightadministrations of medications such as: a nurse who does not inform the route of administration of the medication, not tell about a given dose and nurses who are not documented in the records of medication administration (Nguyen, et al, 2015).

According to the assumptions of researchers based on the results of questionnaires known that nursing service is good and the patient satisfied with nursing care especially in application of six right on medication administration. Nurse have done in accordance with existing procedures and able to perform well. In doing six rights on medication administration, nurses can communicate properly to the patient by providing an explanation that can be understood by the patient (Gonzales, 2012). In providing nursing care, the nurse is able to cooperate with the patient so that the patient's problem can be resolved properly and patients are satisfied with their care. When nurse provide the medication safely, it will avoid medication errors as well (Gorgich, et al, 2015).

\section{CONCLUSIONS}

This study concluded that the implementation of six rights on medication administration by nure are done well. A half of respondents who were satisfied with the application of the six rights on medication administration. Then, there is a significant relationship between application of six rights on medication administration by nurses and patient satisfaction. It was expected to improve or maintain the role in the application of six rights on medication administration so that it will impact to the satisfaction of the patients as recipients of nursing services.

\section{Implication for nursing services}

Then, it suggested to the nurses, that have attend trainings or counseling related to the implementation of six right on medication administration conducted in the hospital or outside of the hospital. The results of this study, when viewed from the aspect of management will have implications on the quality of care. Improving the skill about six right on medication administration by nurses may achieve patient satisfaction and excellent service in the hospital especially in nursing care. 


\section{Acknowledgement}

This research was supported by LPPM STIKes Fort De Kock Bukittinggi as a research centre. We thank to the respondents, who extended their immense help by providing the required information, which in turn helped in achieving the objective information of this study. We are also immensely grateful to the reviewer team of the journal for their comments on an earlier version of the manuscript, although any errors are our own and should not tarnish the reputations of these esteemed persons.

\section{REFERENCES}

Abdul, Saleh, \& Sjattar. (2013). Hubungan Perilaku Caring Perawat Dengan Tingkat Kepuasan Pasien Rawat Inap Rumah Sakit.

Adisasmito, W. (2014). Sistem Kesehatan. Edisi 2. Jakarta: Rajawali Pers

Aiken, L. H., Sermeus, W., Van den Heede, K., Sloane, D. M., Busse, R., McKee, M., ... Kutney-Lee, A. (2012). Patient safety, satisfaction, and quality of hospital care: cross sectional surveys of nurses and patients in 12 countries in Europe and the United States. BMJ, 344(1717), 1-14. https://doi.org/10.1136/bmj.e1717

Brooks-Carthon, J. M., Kutney-Lee, A., Sloane, D. M., Cimiotti, J. P., \& Aiken, L. H. (2011). Quality of care and patient satisfaction in hospitals with high concentrations of black patients. Journal of Nursing Scholarship, 43, 301-310. https://doi.org/http://dx.doi.org/10.1111/j .1547-5069.2011.01403.x

Gonzales, K. J. (2012). Assessments of Safe Medication Administration in Nursing Education. Journal of Nursing Education and Practice, 2(1), 39-50. https://doi.org/10.5430/jnep.v2n1p39

Gorgich EA1, Barfroshan S, Ghoreishi G, Y. M. (2015). Investigating the Causes of Medication Errors and Strategies to Prevention of Them from Nurses and Nursing Student Viewpoint. Glob $J$ Health Sci., 8(8), 220-227. https://doi.org/10.5539/gjhs.v8n8p220

Hilmawan, F. A., Suprapti, E., \& Solechan, A. (2014). Hubungan Antara Penerapan Standart Operational Procedure (SOP) Pemberian Obat Prinsip Enam Benar Dengan Tingkat Kepuasan Pasien Di
RSUD Ungaran. Jurnal Ilmu Keperawatan Dan Kebidanan, 1-10.

Hughes, R. G., \& Blegen, M. a. (2008). Chapter 37 . Medication Administration Safety. Patient Safety and Quality: An Evidence-Based Handbook for Nurses Vol. 2, 1-62.

Huynh, N., Snyder, R., Vidal, J. M., Sharif, O., Cai, B., Parsons, B., \& Bennett, K. (2016). Assessment of the Nurse Medication Administration Workflow Process. Journal of Healthcare Engineering, 2016. https://doi.org/10.1155/2016/6823185

Kaasalainen, S. (2014). Medication administration. Canadian Fundamentals of Nursing, 662-750.

Kartika, I. R. (2014). Nursing Care Quality Indicators and Patient Satisfaction in the Hospital: a systematic review. The 1st International Conference on Education and Nursing Research, 1(1), 73-79.

Kartika, I. R. (2015). Affective Support By Nurse on Outpatient Satisfaction in Nursing Care. The International Conference on Fort De Kock Health Science College, 1(1), 66-74.

Kartika, I. R. (2016). Kepuasan Pasien Terhadap Interaksi Perawat Dalam Pemberian Informasi Kesehatan. Jurnal Keperawatan Fort De Kock, 3(1), 53-61.

Kutney-Lee, A., McHugh, M. D., Sloane, D. M., Cimiotti, J. P., Flynn, L., Neff, D. F., \& Aiken, L. H. (2009). Nursing: A key to patient satisfaction. Health Affairs, 28(4), 669-677.

https://doi.org/10.1377/hlthaff.28.4.w669

McLeod, M., Barber, N., \& Franklin, B. D. (2015). Facilitators and barriers to safe medication administration to hospital inpatients: A mixed methods study of nurses' medication administration processes and systems (the MAPS study). PLoS ONE, 10(6), 1-21. https://doi.org/10.1371/journal.pone.0128 958

Nguyen, H. T., Nguyen, T. D., Van Den Heuvel, E. R., Haaijer-Ruskamp, F. M., \& Taxis, K. (2015). Medication errors in Vietnamese hospitals: Prevalence, potential outcome and associated factors. PLoS ONE, 10(9), 1-13. https://doi.org/10.1371/journal.pone.0138 284

Otani, K., Waterman, B., Faulkner, K. M., 
Boslaugh, S., Burroughs, T. E., \& Dunagan, W. C. (2009). Patient satisfaction: focusing on "excellent." Journal of Healthcare Management / American College of Healthcare Executives, 54(2), 93.

Pirinen, H., Kauhanen, L., Danielsson-ojala, R., Lilius, J., Tuominen, I., Rodríguez, N. D., \& Salanterä, S. (2015). Registered Nurses , Experiences with the Medication Administration Process. Advances in Nursing, 2015(1), 1-10. https://doi.org/10.1155/2015/941589

Senarath, U., Gunawardena, N. S., Sebastiampillai, B., Senanayake, A., Lekamge, S., Seneviratna, A., ... Wijeratne, D. (2013). Patient satisfaction with nursing care and related hospital services at the National Hospital of Sri Lanka. Leadership in Health Services, 26(1), 63-77.

https://doi.org/http://dx.doi.org/10.1108/1

7511871311291732 